\title{
Competitiveness of regions with similar meteorological conditions of agricultural production
}

\author{
Elena Kolomeeva ${ }^{1, *}$, Anna Kharitonova ${ }^{1}$, and Natalia Zaruk ${ }^{1}$ \\ ${ }^{1}$ Russian State Agrarian University - Moscow Timiryazev Agricultural Academy, 127550 Moscow, \\ Russia
}

\begin{abstract}
The article contains regions differentiation on competitiveness of agricultural production taking into account meteorological conditions. Regions with favorable and unfavorable conditions of agriculture were identified. The direct competitiveness dependence of subjects of the Russian Federation on the climate factor is revealed; in the future it will allow to determine ways of increasing productivity and efficiency of agricultural activities and will increase the competitiveness of individual regions. In each group, the most and least competitive subjects for crop production and livestock are identified.
\end{abstract}

\section{Introduction}

In modern conditions, the relevance of competitiveness rating estimates of regions of Russia is necessary for the authorities and administrations to determine priorities in the development of regional economic policies aimed at ensuring national competitiveness [1, 2].

The authors believe that competitiveness is the basis of agricultural production efficiency. Competitive advantages based on efficient use of available resources determine the development level of the region in the context of socio - economic, innovative, information, and other transformations of the society life.

The climatic factor has a priority value for agricultural production. At the same time, climate changes occurring in individual regions can have a significant impact on global exports and imports. In particular, in Kazakhstan, the rainfall increase by 1 millimeter during the main vegetative period from May to August will increase wheat exports by $0.7 \%$ and reduce imports by $1.7 \%$; temperature increase by $1^{\circ} \mathrm{C}$ during the same season will significantly increase wheat exports by $21.9 \%$ and reduce imports by $49.4 \%$ [3]. Temperature changes in certain regions of the Russian Federation also adversely affect the country's food security. Agricultural product losses in adverse years result in a decrease in gross value added by up to $12 \%$ [4]. As a result, agricultural production needs to be distributed so that product losses due to meteorological conditions are offset by the production of other regions. Therefore, it is necessary to assess the regions' competitiveness primarily based on their climatic conditions.

* Corresponding author: kolomeeva@rgau-msha.ru 


\section{Materials and methods}

In terms of agricultural production, the regions' competitiveness also depends on the potential of individual regions for economic, social and environmental development $[4,5]$. As a result, it is necessary to study a set of statistical indicators reflecting all aspects of the phenomena under consideration.

The purpose of the analysis is to differentiate the regions of the Russian Federation on competitiveness of agricultural production considering climate factors. The analysis process can be carried out in several stages.

The first stage is the grouping of regions of the Russian Federation according to the regulatory level of heat availability (average daily air temperature for May-July). Competitiveness needs to be assessed among regions with similar opportunities for agricultural production. Dividing regions into federal districts do not consider the climate factor, as a result it is necessary to identify groups with similar climate productivity. Therefore, it is advisable to consider and analyze areas separately with favorable and adverse climatic conditions of agricultural activity.

The second stage of the analysis is the calculation of the indicators system for the selected groups in comparison by year. For the analysis, a five-year period was considered to characterize sustainability of indicators.

The third stage is to identify the most and least competitive regions for crop and livestock production in each of the selected groups. According to the main indicators characterizing the relevant industry, it is necessary to rationalize variables according to the formula of linear scaling [7]:

$$
I_{i}=\frac{x_{i}-x_{\min }}{x_{\max }-x_{\min }}
$$

where $I_{i}$ is the index of the $i$-th region for the given factor;

$\mathrm{x}_{\mathrm{i}}$ is the value of the factor in the $\mathrm{i}$-th region;

$\mathrm{x}_{\min }$ is the minimum value from the assemblage of regions;

$\mathrm{x}_{\max }$ is the maximum value from the assemblage of regions.

The integral indicator will be defined as the arithmetic mean of the calculated indices for each factor.

\section{Results and discussions}

Dynamic impact assessment of meteorological factors on the state and agriculture productivity in conditions of climate change on the territory of the country, accounting of which will allow to determine ways to increase productivity and efficiency of agricultural activities and identify the most competitive regions.

The competitiveness of the regions depends primarily on the conditions of agricultural production. Due to the vast territory of the Russian Federation, regions are characterized by a variety of natural and climatic conditions $[1,8]$. Therefore, for analysis, it is necessary to group regions by the regulatory level of heat availability (average daily air temperature for May-July).

According to the grouping results, it should be noted that regions with an average temperature of growing period of only $12.3^{\circ}$ (34 regions) predominate. This group accounts for $85 \%$ of the country's territory and only a third of the agricultural land. The average productivity score characterizes group I of regions as the least productive. There is essentially a focal farming with a specific weight of farmland in the total land area of only $5.7 \%$. It is advisable to include 20 regions with an average daily temperature of $15.6^{0}$ in the group II. The regions with the highest average daily air temperature of $18.3^{0}$ respectively 
(23 regions) were assigned to group III. Groups II and III account for only $15 \%$ of the country and $62 \%$ of all agricultural land. The average climate productivity score for group II and III regions is higher than the group I by 21 and 27\% respectively. The proportion of agricultural land is $34.7 \%$ and $77.3 \%$ respectively. Thus, the III group of regions can be described as the most productive for agriculture.

Let us consider changes in the temperature regime of 2014 compared to 2018 (table 1).

Table 1. Grouping of subjects of the Russian Federation according to average daily air temperature for May-July

\begin{tabular}{|c|c|c|c|c|}
\hline \multirow{2}{*}{ Indicators } & \multicolumn{3}{|c|}{ Regions groups } & \multirow{2}{*}{ On average } \\
\cline { 2 - 4 } & 1 & II & III & 77 \\
\hline Number of subjects of Russia & 34 & 20 & 23 & \\
\hline Average temperature, C : & & & & \\
\hline July: 2014 & 16,4 & 18,3 & 22,1 & 18,6 \\
\hline 2018 & 17,2 & 20,1 & 23,4 & 19,8 \\
\hline difference of 2018 and 2014 & 0,8 & 1,7 & 1,3 & 1,2 \\
\hline January: 2014 & $-16,8$ & $-13,0$ & $-6,7$ & $-12,8$ \\
\hline 2018 & $-15,5$ & $-10,3$ & $-5,2$ & $-11,0$ \\
\hline difference of 2018 and 2014 & 1,3 & 2,7 & 1,5 & 1,8 \\
\hline Amount of precipitation, mm: & & & & \\
\hline July: 2014 & 68,1 & 52,9 & 33,2 & 53,7 \\
\hline 2018 & 74,4 & 90,1 & 87,3 & 82,3 \\
\hline difference of 2018 and 2014 & 6,3 & 37,2 & 54,1 & 28,6 \\
\hline January: 2014 & 30,6 & 33,4 & 51.5 & 37,6 \\
\hline 2018 & 31,5 & 34,1 & 39,0 & 34,4 \\
\hline difference of 2018 and 2014 & 0,9 & 0,8 & $-12,6$ & $-3,1$ \\
\hline
\end{tabular}

Weather conditions in 2018 were different from 2014. Thus, the national average daily air temperature in July is higher by $1.2^{\circ} \mathrm{C}$. In group I regions, the differences were the smallest (only $0.8^{\circ} \mathrm{C}$ ). Similarly, in January 2018 the temperature was higher than 2014 by $1.8^{\circ} \mathrm{C}$. Significant differences are visible in the amount of July rainfall. Overall, the country had 53\% more precipitation in 2018 compared to 2014. In the regions with the warmest weather conditions, precipitation was 1.5 times higher. Thus, it should be noted that meteorological conditions are more stable in the regions with the most adverse agricultural production conditions compared to warmer subjects.

Table 2. Productivity of selected groups according to average daily air temperature for May-July

\begin{tabular}{|c|c|c|c|c|}
\hline \multirow{2}{*}{ Indicators } & \multicolumn{3}{|c|}{ Regions groups } & \multirow{2}{*}{ On average } \\
\hline & 1 & II & III & \\
\hline \multicolumn{5}{|l|}{ Per 1 region: } \\
\hline Agricultural products, billion rubles: 2014 & 31,14 & 51,06 & 79,38 & 51,09 \\
\hline 2018 & 38,98 & 64,69 & 111,52 & 67,89 \\
\hline Gross grain harvest (in weight after refinement), & 514,51 & 741,48 & 2996,22 & 1353,66 \\
\hline
\end{tabular}




\begin{tabular}{|c|c|c|c|c|}
\hline \multicolumn{5}{|l|}{ thousand tons: 2014} \\
\hline 2018 & 572,01 & 892,32 & 3133,11 & 1460,90 \\
\hline $\begin{array}{l}\text { Production of livestock and poultry for } \\
\text { slaughter, thousand tons: }\end{array}$ & 68,15 & 116,57 & 176,65 & 113,95 \\
\hline 2018 & 73,81 & 144,91 & 213,27 & 134,95 \\
\hline \multicolumn{5}{|l|}{$\begin{array}{l}\text { Implementation of the main types of } \\
\text { agricultural products by agricultural } \\
\text { organizations, thousand tons: }\end{array}$} \\
\hline livestock and poultry (in live weight): 2014 & 63,87 & 127,97 & 177,80 & 115,36 \\
\hline 2018 & 73,26 & 167,27 & 228,74 & 145,20 \\
\hline grain: 2014 & 208,73 & 275,49 & 1774,38 & 707,59 \\
\hline 2018 & 234,01 & 429,07 & 2220,75 & 895,33 \\
\hline milk: 2014 & 140,38 & 264,28 & 139,60 & 171,91 \\
\hline 2018 & 152,50 & 303,96 & 168,65 & 196,30 \\
\hline $\begin{array}{l}\text { Yield of grains and legumes (in weight after } \\
\text { refinement), hwt/ha of harvested area: } 2014\end{array}$ & 19,27 & 19,92 & 30,83 & 22,01 \\
\hline 2018 & 20,38 & 21,45 & 32,06 & 22,68 \\
\hline $\begin{array}{l}\text { Milk yield per cow in agricultural } \\
\text { organizations, kg: } 2014\end{array}$ & 4159,6 & 4626,0 & 4578,9 & 4349,5 \\
\hline 2018 & 4974,8 & 5645,5 & 5797,9 & 5198,1 \\
\hline $\begin{array}{l}\text { Fodder consumption per notional head of cattle } \\
\text { in agricultural organizations, hwt fodder units: } \\
2014\end{array}$ & 27,45 & 33,11 & 27,02 & 28,77 \\
\hline 2018 & 28,06 & 32,40 & 27,86 & 28,75 \\
\hline
\end{tabular}

The climate factor plays a special role for agricultural production as seen from the grouping results (table 2). Agriculture products are growing from group to group. In 2014, the III group of regions exceeded I by 1.55 times, in 2018 - by 2.86 times. Also in all groups there is a noticeable increase in gross grain harvest and production of livestock and poultry for slaughter relative to 2014, with the highest rate of growth among the II group of regions ( 20 and $24 \%$ respectively).

The implementation of the main types of agricultural products by agricultural organizations increased in 2018 relative to 2014 in regions of all groups. In grain sales, regions of the III group significantly exceed all others (1.5 times higher than the national average), corresponding to the highest grain yield (1.4 times higher than the national average). However, milk is sold by the regions of the II group and outnumber the III group by 1.8 times with almost equal levels of milk yield per cow. Thus, it is possible to note the specialization of the II group regions on milk sales.

Table 3. Economic efficiency of allocated groups on average daily air temperature for May-July

\begin{tabular}{|c|c|c|c|c|}
\hline \multirow{2}{*}{ Indicators } & \multicolumn{3}{|c|}{ Regions groups } & \multirow{2}{*}{$\begin{array}{c}\text { On } \\
\text { average }\end{array}$} \\
\hline & 1 & II & III & \\
\hline \multicolumn{5}{|l|}{ Per 1 thousand $\mathrm{km}^{2}$ area: } \\
\hline $\begin{array}{l}\text { gross regional product, million rubles: } \\
2014\end{array}$ & 1445,6 & 8084,6 & 9739,0 & 2546,4 \\
\hline 2017 & 1844,6 & 10289,0 & 11904,3 & 3211,9 \\
\hline $\begin{array}{c}\text { Balanced financial result } \\
\text { (profit minus loss) of organizations, thousand }\end{array}$ & & & & \\
\hline
\end{tabular}




\begin{tabular}{|c|c|c|c|c|}
\hline $\begin{array}{c}\text { rubles on average per hectare of agricultural } \\
\text { land: }\end{array}$ & & & & \\
\hline crop production: 2014 & 29,72 & 18,35 & 634,52 & 270,11 \\
\hline 2018 & 63,07 & 114,90 & 1039,81 & 467,08 \\
\hline livestock farming: 2014 & 447,37 & 231,82 & 815,33 & 547,34 \\
\hline 2018 & 382,03 & 334,18 & 614,61 & 464,89 \\
\hline $\begin{array}{c}\text { Profitability of sold goods, products (works, } \\
\text { services) of organizations carrying out activities } \\
\text { in crop production and animal husbandry, } \% \text { : }\end{array}$ & & & & \\
\hline Crop production 2014 & 7,90 & 11,66 & 17,50 & 11,41 \\
\hline 2018 & 8,15 & 10,79 & 1,73 & 6,44 \\
\hline livestock farming: 2014 & 2,49 & 10,14 & 17,90 & 8,83 \\
\hline 2018 & 3,37 & 2,24 & 7,63 & 4,29 \\
\hline $\begin{array}{c}\text { Share of loss-making organizations engaged in } \\
\text { activities in crop production and livestock, } \\
\text { hunting and provision of related services in } \\
\text { these areas, } \% \text { : } 2014\end{array}$ & & & & \\
\hline 2018 & 59,04 & 29,37 & 25,34 & 29,25 \\
\hline
\end{tabular}

The level of economic development is also increasing from group to group. Thus, the gross regional product relative to the area of the III group regions is higher than the I group in 2014 by 6.7 times, and in 2017. (data on GRP for 2018 has not yet been published) 6.45 times. Balanced financial result of organizations relative to agricultural land for crop production in regions of the III group is higher than the national average more than 2 times. Despite large volumes of milk sales, II group regions' balanced financial result of animal husbandry organizations is even lower than in the I group of regions. Accordingly, the II group regions have the lowest profitability of sold goods, products (works, services) of organizations that carry out activities in animal husbandry. This happened mainly due to unprofitability of such regions as Yaroslavl Oblast (-41.3\%), Chuvash Republic (-30\%), Udmurt Republic $(-18,5)$ and Mari El Republic $(-11.4 \%)$. This may be due to the fact that the regions of this group mainly sell unprofitable products such as cattle meat.

The profitability of sold goods, products (works, services) of organizations that carry out activities in crop production and animal husbandry in 2014 increases from group to group. However, lower profitability of the III group organizations in crop production in 2018 (1.73\% total) should be noted. This was affected by unprofitability of such regions as Penza oblast (-48.6\%), Tula oblast (-42.7\%), Republic of Adygea (36.7\%) and others.

In general, a decrease in the proportion of loss-making organizations engaged in activities in crop and animal husbandry, hunting and provision of related services in these areas in I group of regions by 2018 should be noted. However, the proportion increased slightly in other groups of regions. This shows a decrease in the indicator from group to group.

Agricultural producer's prices and sales prices are important to assess competitiveness. The indicators were considered for 2014, 2018 and for the first half of 2020 as a comparison of general nature by region.

Table 3. Prices of the main types of agricultural products

\begin{tabular}{|l|r|r|r|r|}
\hline \multirow{2}{*}{ Indicators } & \multicolumn{3}{c|}{ Regions groups } & \multirow{2}{*}{$\begin{array}{c}\text { On } \\
\text { average }\end{array}$} \\
\cline { 2 - 4 } & 1 & \multicolumn{1}{c|}{ II } & \multicolumn{1}{c|}{ III } & \\
\hline \multicolumn{2}{|c|}{ Average prices of agricultural products' producers sold by agricultural organizations } \\
\hline $\begin{array}{l}\text { Grain and leguminous crops, thousand rubles / } \mathrm{t}: \\
2014\end{array}$ & 6,90 & 6,77 & 6,55 & 6,74 \\
\hline
\end{tabular}




\begin{tabular}{|c|c|c|c|c|}
\hline 2018 & 8,23 & 7,61 & 8,48 & 8,14 \\
\hline 2020 (January-August) & 10,35 & 10,74 & 11,28 & 10,80 \\
\hline Raw cattle milk, thousand rubles/t.: 2014 & 23,72 & 19,67 & 19,38 & 21,37 \\
\hline 2018 & 28,51 & 22,88 & 24,19 & 25,74 \\
\hline 2020 (January-August) & 34,44 & 26,21 & 25,90 & 29,69 \\
\hline Cattle, thousand rubles/t.: 2014 & 160,51 & 157,50 & 142,04 & 155,10 \\
\hline 2018 & 107,99 & 97,30 & 104,17 & 103,97 \\
\hline 2020 (January-August) & 112,72 & 106,01 & 112,45 & 110,87 \\
\hline Fresh chicken eggs in shell, rub./pcs: & 4,16 & 3,33 & 3,50 & 3,76 \\
\hline 2018 & 4,77 & 3,60 & 3,95 & 4,21 \\
\hline 2020 (January-August) & 5,08 & 3,90 & 4,17 & 4,49 \\
\hline \multicolumn{5}{|c|}{ Average sales prices of agricultural products by farmers of all categories } \\
\hline $\begin{array}{l}\text { Grain and leguminous crops, thousand rub./t.: } \\
2014\end{array}$ & 6,77 & 6,97 & 6,64 & 6,78 \\
\hline 2018 & 8,03 & 7,29 & 8,24 & 7,89 \\
\hline 2020 (1-2 quarter) & 10,33 & 10,78 & 11,06 & 10,72 \\
\hline Raw cattle milk, thousand rubles/t.: 2014 & 26,50 & 21,04 & 21,58 & 23,59 \\
\hline 2018 & 33,99 & 24,25 & 27,50 & 29,52 \\
\hline 2020 (1-2 quarter) & 79,69 & 54,31 & 61,52 & 67,59 \\
\hline Cattle, thousand rubles/t.: 2014 & 185,40 & 193,07 & 200,89 & 191,89 \\
\hline 2018 & 121,57 & 106,07 & 123,33 & 118,05 \\
\hline 2020 (1-2 quarter) & 128,83 & 120,88 & 137,44 & 129,46 \\
\hline Chicken eggs, rubles/pcs.: 2014 & 4,34 & 4,29 & 3,84 & 4,17 \\
\hline 2018 & 5,21 & 4,58 & 4,99 & 4,98 \\
\hline 2020 (1-2 quarter) & 5,64 & 5,05 & 5,38 & 5,40 \\
\hline
\end{tabular}

Average prices of agricultural products' producers of grains and legumes sold by agricultural organizations in 2014 in regions III were the lowest, as were sale prices. However, in 2018 the prices of both producers and product sales in the III group became the highest. This remains the case for 2020.

The agricultural products producers' prices and sales of raw cattle milk is the highest in the regions of the I group with the most unfavorable conditions of agriculture production. Prices of group III regions are lower than the national average for all considered years (in 2014 and 2020 prices were the lowest among the groups under consideration). Sales prices of raw cattle milk for all considered years are the lowest in the regions of the II group. Group III regions occupy an intermediate position. In general, significant differences in producers prices and sales in 2020 should be noted (the national average difference is 37.9 thousand rub./t). However, data for 2020 are published only from January to August, so differences can be attributed to seasonality and it is still quite early to draw reliable conclusions.

For cattle prices, strong differences between producer prices and sales can also be noted. Particularly noticeable are differences in 2014 for regions of the III group: producer prices were the lowest in the country (142 thousand rub./t), and sales prices were maximum (200.88 thousand rub./t). Thus, the difference amounted to 58,85 thousand rub./t. In 
general, the differences between groups for cattle prices in 2018 and 2020 do not vary much between each other.

Prices for chicken eggs are also the highest in the regions of group I . The lowest producer's prices are in group II regions, but sales prices exceed group III.

Thus, II and III group regions can be said to be the most competitive. These regions are characterized by favorable weather conditions with consequently higher productivity, lower costs for growing agricultural products and lower producer's prices.

In each of the groups considered, we will conduct a rating assessment of the regions on crop production and livestock production. To assess the competitiveness of regions on crop production we will consider the following indicators system: profitability of sold goods, products (works, services) of organizations implementing activity in crop production; yield of grain and leguminous crops, GRP per 1 ha of agricultural land, sold grain per 1 ha of agricultural land.

Let us consider the 3 "best" and 3 "worst" regions in each group (table 4 ).

Table 4. Rating of regions by crop industry

\begin{tabular}{|c|c|c|c|}
\hline Region & $\begin{array}{c}\text { Ranking } \\
\text { place }\end{array}$ & Region & $\begin{array}{c}\text { Ranking } \\
\text { place }\end{array}$ \\
\hline \multicolumn{4}{|c|}{ III Group of regions } \\
\hline Krasnodar Krai & 1 & Orenburg Oblast & 22 \\
\hline $\begin{array}{c}\text { Republic of North Ossetia - } \\
\text { Alania }\end{array}$ & 2 & Republic of Kalmykia & 23 \\
\hline Belgorod Oblast & 3 & Republic of Adygea & 24 \\
\hline \multicolumn{4}{|c|}{ II Group of regions } \\
\hline Moscow oblast & 1 & Chelyabinsk oblast & 18 \\
\hline Bryansk Oblast & 2 & Tver Oblast & 19 \\
\hline Republic of Tatarstan & 3 & Yaroslavl Oblast & 20 \\
\hline \multicolumn{4}{|c|}{ I Group of regions } \\
\hline Kaliningrad Oblast & 1 & Kostroma Oblast & 32 \\
\hline Altai Krai & 2 & Khabarovsk Krai & 33 \\
\hline Murmansk Oblast & 3 & Magadan Oblast & 34 \\
\hline
\end{tabular}

In the III group of regions with the most favorable conditions of agricultural production, the most competitive region is Krasnodar Krai. The indicators of the region exceed all the other indicators under consideration. The least competitive of this group of regions are the Orenburg oblast, the Republic of Kalmykia and the Republic of Adygea. Despite favorable climatic conditions in these regions, the crop industry is poorly developed.

In the II group of regions, Moscow oblast, Bryansk oblast and the Republic of Tatarstan are the most profitable. Crop production is developed in these regions despite the temperate climate. The least efficient are: Chelyabinsk, Tver and Yaroslavl oblasts.

In the I group of regions with unfavorable conditions of agricultural production the most competitive are Kaliningrad Oblast, Altai Krai and Murmansk Oblast. Despite small volumes, production and sale of crop production in these regions is effective. The least competitive regions are: Kostroma Oblast, Khabarovsk Krai and Magadan Oblast. In these regions grains and legumes are barely grown.

Similarly, the most and least competitive regions for livestock were identified (table 5). The following indicators were considered: profitability of goods sold, products (works, services) of organizations engaged in animal husbandry, number of cattle per 1 hectare of 
fodder crops, sold cattle and poultry per 1 ha of feed crops sowing, number of poultry per 1 ha of feed crops sowing, milk yield per 1 cow, sold milk per 1 cattle head.

Table 5. Rating of regions by livestock industry

\begin{tabular}{|c|c|c|c|}
\hline Region & $\begin{array}{c}\text { Ranking } \\
\text { place }\end{array}$ & Region & $\begin{array}{c}\text { Ranking } \\
\text { place }\end{array}$ \\
\hline \multicolumn{4}{|c|}{ III Group of regions } \\
\hline Belgorod Oblast & 1 & Republic of Kalmykia & 22 \\
\hline Lipetsk Oblast & 2 & Ulyanovsk Oblast & 23 \\
\hline Krasnodar Krai & 3 & Orenburg Oblast & 24 \\
\hline \multicolumn{4}{|c|}{ II Group of regions } \\
\hline Moscow oblast & 1 & Chuvash Republic & 18 \\
\hline Republic of Mordovia & 2 & Smolensk Oblast & 19 \\
\hline Mari El Republic & 3 & Kurgan Oblast & 20 \\
\hline \multicolumn{4}{|c|}{ I Group of regions } \\
\hline Leningrad Oblast & 1 & Republic of Tyva & 32 \\
\hline Murmansk Oblast & 2 & Magadan Oblast & 33 \\
\hline Vologda Oblast & 3 & $\begin{array}{c}\text { Chukotka Autonomous } \\
\text { Okrug }\end{array}$ & 34 \\
\hline
\end{tabular}

In the III group of regions due to favorable climatic conditions, the most competitive are Belgorod Oblast, Lipetsk Oblast and Krasnodar Krai. It should be noted that the leaders in both crop production and livestock are Belgorod Oblast and Krasnodar Krai. Thus, they can be recognized as the most profitable regions for agriculture as a whole. Among the least competitive regions with favorable conditions of agriculture, the Republic of Kalmykia and Orenburg oblast occupy low positions in crop and livestock production. Consequently, despite favorable conditions, agriculture in these regions is poorly developed.

In the II group of regions the leading position is also held by the Moscow oblast. Therefore, it can be recognized as the most profitable in all agricultural production. Animal husbandry is also developed in the Republics of Mordovia and Mari El. Among the least competitive regions in animal husbandry the Chuvash Republic, Smolensk Oblast and Kurgan Oblast can be noted.

Among the regions with unfavorable conditions of agricultural production, livestock production is most developed in Leningrad, Murmansk and Vologda oblasts. Murmansk oblast should be recognized as the most competitive in all agricultural production. In such entities as the Republic of Tyva, Magadan oblast and the Chukotka Autonomous Okrug, animal husbandry is barely developed. Magadan oblast is overall the least agriculturally competitive.

\section{Conclusions}

The formation of regional competitiveness and its assessment are the most important tasks of ensuring the sustainable development of agriculture both in the individual region and in the Russian Federation as a whole.

The basis of the methodology proposed by the authors of agricultural production regional competitiveness assessment is differentiation of regions of the Russian Federation considering climate factors. In this regard, the agricultural production competitiveness 
assessment should begin by grouping regions according to the regulatory level of heat availability (average daily air temperature for May-July).

The authors propose an indicators competitiveness assessment system in the context of the selected groups of regions. Thus, to assess the regional competitiveness of crop production, the following indicators system is proposed: profitability of sold goods, products (works, services) of organizations carrying out activity in crop production, yield of grain and leguminous crops, GRP per 1 ha of agricultural land, sold grain per 1 ha of agricultural land; for livestock products: profitability of sold goods, products (works, services) of organizations carrying out activities in livestock, total head of livestock per 1 hectare of fodder crops, sold cattle and poultry per 1 ha of feed crops sowing, total head of poultry per 1 ha of fodder crops, milk yield per 1 cow, sold milk for 1 head of cattle.

In the context of each selected group, the most and least competitive regions for crop and livestock were identified.

The method proposed by the authors allows to comprehensively assess the competitiveness of agriculture in the context of regions with similar natural and climatic conditions, as well as to carry out positioning of a single region within the selected groups, which will allow to determine the strengths and weaknesses of the subject in terms of efficiency of agricultural production and to establish approaches to their elimination.

\section{Acknowledgment}

The article was prepared with the financial support of RSAU-MAA named after K.A. Timiryazev, the topic of the project "Model of efficient agriculture of Russia on the basis of increasing competitiveness in conditions of integration deepening" No.4.

\section{References}

1. S.A. Golovykhin, A.I. Valetov, 3,157-161 (2015)

2. E.S. Kolomeeva, Economics of agriculture, 4, $72-78$ (2017)

3. X. Yu, H. Luo, H. Wang, J.-H. Feil, Ecosystem health and sustainability, 6(1), 1-9 (2020) https://doi.org/10.1080/20964129.2020.1766380

4. A.P. Zinchenko, A.E. Kharitonova, Economics of agricultural and processing enterprises, 4, 16-19 (2014)

5. M.V. Kagirova, O.A. Rodionova, A.D. Dumnov, V.E. Kerimov, E.S. Kolomeeva, Journal of Applied Economic Sciences, 13, 4(58), 1069-1080 (2018)

6. X. Liang, D. Si, X. Zhang, Int J Environ Res Public Health, 14(10) (2017) URL: https://www.ncbi.nlm.nih.gov/pmc/articles/, doi:10.3390/ijerph14101219

7. O.I. Rashidov, Economics and Management, 9(82), 112-116 (2011)

8. A.E. Kharitonova, Questions of statistics, 25(10), 37-46 (2018) 